\title{
The Effects of Undergraduate Students' Adult Attachment on Interpersonal Problem: Mediating effects of Cognitive Emotion Regulation Strategy
}

\author{
Du Ri Kwon, Nana Shin \\ Department of Child Development \& Intervention, Ewha Womans University, Seoul, Korea \\ 대학생의 성인애착이 대인관계문제에 미치는 영향: \\ 인지적 정서조절 전략의 매개효과 \\ 권두리, 신나나 \\ 이화여자대학교 아동학과
}

Objective: The main purpose of this study was to examine the mediating effects of cognitive emotion regulation strategies on the relationship between undergraduate students' adult attachment and interpersonal problems.

Methods: A total of 300 undergraduate students participated in this study. They completed a questionnaire regarding adult attachment, cognitive emotion regulation strategies, and interpersonal problems.

Results: First, undergraduate students' adult attachment was significantly related to interpersonal problems. Attachment anxiety had a greater influence on interpersonal problems than attachment avoidance. Second, adult attachment was significantly associated with cognitive emotion regulation strategies. Third, cognitive emotion regulation strategies were significantly related to interpersonal problems. Forth, cognitive emotion regulation strategies partially mediated the relations between attachment-related anxiety and avoidance and interpersonal problems.

Conclusion: This study highlights the importance of adult attachment in interpersonal relationships among undergraduate students. Based on the results from this study, it would be important to further develop counseling programs to help reduce the interpersonal problems of undergraduates at the educational environment.

Keywords: adult attachment, cognitive emotion regulation strategy, interpersonal problem$$
\text { 서론 }
$$

인간은 출생 후 전 생애에 걸쳐 타인과 교류하고, 관계를 맺 으며 살아간다. 생애 초기에는 주 양육자와 애착 관계를 형성 하고, 아동 및 청소년기에는 또래관계의 중요성이 부각되며, 성인기가 되면 대학 혹은 직장 등 사회로 진출함에 따라 다양

Corresponding Author: Nana Shin, Department of Child Development \& Intervention, Ewha Womans University, 52 Ewhayeodae-gil, Seodaemungu, Human Ecology Building 402-1, Seoul, 03760, Korea

E-mail: nanashin@ewha.ac.kr
\end{abstract}

한 사람들과 폭넓은 관계를 형성하게 된다. 특히 대학생 시 기는 Erikson $(1963,1980)$ 의 심리사회적 발달단계 중 성인 전 기에 해당하는 시기로, 친밀감이라는 발달과업을 형성해야 하는 시기이다. 그러나 Arnett (2000)이 성인진입기(emerging adulthood)라는 새로운 단계를 제안하며 주장한 것처럼, 학업 에 종사하는 기간이 연장되면서 현대의 대학생은 정체성과 친

C)The Korean Association of Child Studies

This is an Open Access article distributed under the terms of the Creative Commons Attribution Non-Commercial License (http:// creativecommons.org/licenses/by-nc/4.0) which permits unrestricted noncommercial use, distribution, and reproduction in any medium, provided the original work is properly cited. 
밀감을 동시에 형성해야 하는 이중 과업에 처해 있다. 특히 고 등학생 시기와 달리 대학생 시기는 정해진 학급 단위에서 벗어 나게 되면서, 대인관계가 선후배, 교수, 학과 생활, 동아리, 진 로 및 대외 활동, 이성 관계 등에 이르는 전반적인 영역으로 그 폭이 넓어지게 된다. 그 결과, 대학생들은 폭넓고 성숙한 대인 관계를 형성해야하는 환경적 변화 속에서 심리적, 사회적 어려 움을 경험할 수 있다. 이 시기 대인관계에서의 어려움은 우울, 불안, 소외, 불행감 등의 정서적 문제를 경험하도록 할 뿐 아니 라(N.-M. Kim \& Kim, 2013; Teyber, 2000), 이후의 사회적 적응 에도 부정적인 영향을 미치기 때문에(Ha \& Jo, 2006; S.-H. Kim $\& \mathrm{Kim}, 2004)$, 성인 전기에 진입한 대학생들이 새로운 환경 속 에서 다양한 사람들과 건강하고 성숙한 대인관계를 형성하는 것은 현재의 적응뿐 아니라 이후의 삶에도 매우 중요하다. 이 에 본 연구에서는 대학생 시기뿐 아니라 졸업 이후의 사회적 적응에 영향을 미칠 수 있는 대학생의 대인관계문제에 주목하 여, 이에 영향을 미치는 선행 변인들을 탐색하였다.

대인관계문제에 영향을 미치는 다양한 변인들 중 성인애 착은 애착이론에서 강조하는 내적작동모델(internal working model)에 기반한 개념으로, 신체적, 정서적 안정감을 얻기 위 해 자신에게 중요한 의미를 가지는 부모, 친구, 연인, 배우자 등과 신체적, 심리적 근접성을 유지하려고 하는 경향성을 의 미한다(Main, Kaplan, \& Cassidy, 1985). 영유아기 애착이 유형 별로 분류되는 것과는 달리, 성인애착은 애착과 관련된 불안 (attachment-related anxiety; 이하 애착 불안)과 애착과 관련된 회피(attachment-related avoidance; 이하 애착 회피)의 두 가지 차원을 포함한다. 각 차원의 특징을 살펴보면(Fraley \& Waller, 1998), 애착 불안의 경우 높을수록 애착대상과의 관계에 지나 치게 몰두하고, 애착대상에게 거절당하거나 버림받기를 두려 워하는 특성을 보인다. 반면 애착 회피는 높을수록 애착대상 과 친밀함을 가지고 관계를 형성하는 것에 불편을 느끼고 회 피하는 경향을 보인다.

성인애착은 관계 속에서 경험하는 불안과 회피이기 때문에 대인관계문제에 미치는 영향을 살펴본 연구들이 지속적으로 수행되어 왔다(Bartholomew \& Horowitz, 1991; Collins \& Read, 1990; Feeney \& Noller, 1990; Haggerty, Hilsenroth, \& Vala-Stewart, 2009; J. U. Kim \& Yang, 2014; Mikulincer, Shaver, \& Pereg, 2003; Moon, 2005; Park \& Lee, 2010; Wei, Vogel, Ku, \& Zakalik., 2005). 예를 들어, J. U. Kim과 Yang (2014)은 애착 불안과 애착 회피 의 수준이 높을수록 대학생이 대인관계에서 문제를 더 많이 경 험하고 있음을 보고하였다. 이와 유사하게 Moon (2005)의 연 구에서도 불안정한 애착을 형성하고 있을수록 대학생의 대인
관계문제 수준이 높았으며, 애착을 유형별로 나누었을 경우에 는 두려움형, 몰두형, 거부형, 안정형 순으로 높은 대인관계문 제를 경험하는 것으로 나타났다. 한편, 애착 불안과 애착 회피 의 특성이 다르기 때문에 각각의 차원이 대인관계에 미치는 영 향에도 차이가 있는 것으로 보고되고 있지만 일관적인 패턴을 보이고 있지는 않다(Kang \& Choi, 2011; J.-H. Lee \& Shim, 2007; Mikulincer et al., 2003; Park \& Lee, 2010; Shin, 2006; Wei et al., 2005). 즉, Park과 Lee (2010)는 대학생의 애착 불안이 애착 회 피보다 대인관계문제와 더 높은 관련성을 보이는 것으로 보고 하였지만, 대학생의 애착 불안보다 애착 회피가 대인관계능력 (Kang \& Choi, 2011)과 대인관계 유능성(Shin, 2006)에 더 큰 영 향력을 미치는 것으로 나타난 연구들도 있어 차이를 보인다.

이렇듯 선행연구들은 성인애착이 대인관계에 중요한 영향 을 미치는 변인이라는 것을 밝히고 있으며, 성인애착이 대인 관계문제에 영향을 미치는 과정에서 다양한 변인들의 역할 을 살펴본 연구들 또한 진행되고 있다. 특히 정서에 중점을 둔 정서조절양식(Kang \& Choi, 2011)이나 정서주의와 정서조절 (Shin, 2006), 우울경험양식(Park \& Lee, 2010) 등과 같은 변인 들이 성인애착이 대인관계에 미치는 영향을 매개하는 변인으 로 연구되어왔다. 보다 최근에는 인지적 측면에 초점을 둔 인 지적 정서조절 전략에 대한 연구들(Garnefski \& Kraaij, 2007; Mikolajczak, Nelis, Hansenne, \& Quoidbach, 2008)이 실시되고 있는데, 인지적 정서조절 전략은 부정적인 정서가 촉발되기 전 이나 정서가 유발된 상태에서 스트레스 상황을 긍정적으로 해 석하거나 인식하는 등 인지적 측면을 변화시킴으로써 정서적 반응을 조절하는 것을 의미한다(Gross, 1998). 인지적 정서조 절 전략은 적응적인 전략과 부적응적인 전략으로 구분되는데 (Garnefski, Kraaij, \& Spinhoven, 2001), 적응적 인지적 정서조절 전략은 스트레스나 부정적인 정서를 유발하는 상황에서 긍정 적인 측면에 초점을 두어 자신의 인지를 변화시켜 정서를 효과 적으로 조절하는 것을 의미하며, 조망확대, 계획 다시 생각하 기, 긍정적 초점변경, 수용, 긍정적 재평가 등이 이에 포함된다. 이러한 적응적 인지적 정서조절 전략은 이미 촉발된 정서를 조 절하기 위해 울음을 터뜨리거나 소리치는 등과 같이 행동적 인 정서조절양식을 보이는 것보다 더 효과적인 것으로 선행연 구들(Garnefski et al., 2001; Garnefski, Legerstee, Kraaij, van den Kommer, \& Teerds, 2002; John \& Gross, 2004)은 보고하고 있다. 반면 부적응적 인지적 정서조절 전략은 그 상황에서 더 부정적 인 측면에 초점을 두고 인지를 변화시켜 유발된 정서를 적응적 이지 못한 방식으로 다루는 전략을 뜻하는 것으로, 자기비난, 타인비난, 반추, 파국화 등이 이에 해당된다. 본 연구에서는 이 
러한 인지적 정서조절 전략에 초점을 두어 성인애착이 대인관 계문제에 미치는 영향을 매개하는지 살펴보았다.

성인애착이 인지적 정서조절 전략에 미치는 영향은 애착이 론(Bowlby, 1969/1982, 1973)을 통해 설명할 수 있는데, 개인은 애착관계 경험을 통해 자신과 타인에 대하여 내재화된 인지적 인 표상을 지니게 되며, 이것이 개인의 정서적 반응에도 영향 을 미치게 된다. 구체적 연구결과들을 살펴보면 Jeon과 Hong (2012)은 애착 불안 수준이 높을수록 적응적 인지적 정서조절 전략을 덜 사용하고, 부적응적 인지적 정서조절 전략을 더 사 용하는 것으로 보고하였으며, Shin (2006)의 연구에서도 불안 정 애착을 형성하고 있을수록 부적응적 인지적 정서조절 전략 을 더 사용하는 것으로 나타났다. 애착 불안과 애착 회피의 영 향이 차이가 있음을 보고한 연구도 있는데, Hwang (2006)은 애 착 불안이 애착 회피보다 적응적 또는 부적응적 정서조절과 더 큰 연관성을 가지고 있음을 밝혔다. 이는 애착 불안이 높을수록 부정적인 자기 표상을 가지고, 자기 효율성에 대한 믿음이 약하 며, 원하지 않는 사고를 억제할 수 있을 만큼 자아가 강하지 않 기 때문에 스트레스나 갈등 상황에서 압도되어 부적응적인 전 략에 의존하기 때문일 가능성이 있다. 이외에도 애착 불안이 높 을수록 과잉활성화 전략을, 애착 회피가 높을수록 비활성화 전 략을 더 사용하는 등 애착 유형에 따라 정서조절 방식에 차이를 보인다는 연구(Cassidy \& Kobak, 1988)가 보고되었다.

인지적 정서조절 전략은 또한 대인관계문제에 영향을 미치 는 것으로 보고되고 있다. 관련하여, 대학생을 대상으로 한 $\mathrm{M}$. J. Kim (2010)의 연구에서는 부적응적 인지적 정서조절 전략 을 사용할수록 대인관계문제의 모든 하위영역의 수준이 높아 지는 것으로 나타났다. 즉, 부적응적 인지적 정서조절 전략의 하위요인인 자기비난, 타인비난, 파국화가 대인관계에서 착 취/통제적이거나 희생/의존적, 그리고 고립/비사회적인 문제 를 더 높였다. 이외에도 인지적 정서조절 전략과 대인관계문 제 및 사회성 간의 관련성을 살펴본 선행연구들(Garnefski \& Kraaij, 2007; E.-Y. Kim, 2009; Mikolajczak et al., 2008)에서는 적 응적 인지적 정서조절 전략을 더 사용할수록 대인관계문제 수 준이 낮아지고 사회성은 높아지며, 부적응적 인지적 정서조절 전략을 더 사용할수록 대인관계문제 수준은 높아지고 사회성 은 낮아지는 것으로 일관적으로 보고하고 있다. 특히 부적응 적 인지적 정서조절 전략 중 반추와 자기비난은 사회성에 부 정적인 영향을 미치는 것으로 나타나(Mikolajczak et al., 2008), 이로 인해 대인관계문제를 경험할 가능성을 시사하고 있다.

지금까지 살펴본 것처럼, 선행연구들은 성인애착이 인지 적 정서조절 전략에 영향을 미치고(Jeon \& Hong, 2012; Shin,
2006), 인지적 정서조절 전략에 따라 대인관계문제의 정도가 달라질 수 있는 것으로 보고하였다(E.-Y. Kim, 2009; M. J. Kim, 2010; Mikolajczak et al., 2008). 이러한 연구들에 기초해 볼 때, 성인애착이 대인관계문제에 영향을 미치는 과정에서 인지적 정서조절 전략이 매개적인 역할을 할 것으로 가정해볼 수 있 다. 실제 이러한 가능성을 탐색한 연구는 매우 드물지만, J.-Y. $\operatorname{Kim}$ (2016)은 대학생을 대상으로 성인애착이 대인관계유능 성에 미치는 영향에서 인지적 정서조절 전략의 매개적 역할을 확인하였다. 또한 인지적 정서조절 전략과 유사하게 부정적인 상황에서 자신의 정서를 효율적으로 조절하는 전략에 초점을 둔 정서조절곤란을 살펴본 연구(D.-W. Lee, 2015)에서는 성인 애착과 대인관계문제 간 관계를 정서조절곤란이 부분매개 한 다는 것을 밝혔다. 애착 불안과 애착 회피 각각이 대인관계문 제에 미치는 영향 또한 차이를 보였는데, 애착 불안이 높을 경 우에는 타인과 관계를 유지하기 위해 자신의 의견이나 생각을 표현하거나 주장하기보다 순응하는 태도와 같은 대인관계문 제를 많이 보인 반면, 애착 회피가 높을 경우에는 타인을 통제 하거나 친밀한 관계를 갖지 못하는 것으로 나타났다. 또한 J. E. Cha (2015)는 애착 불안과 애착 회피 수준이 높을수록 비효 율적이고 부적응적인 정서조절을 하여 대인관계문제에 영향 을 주었을 뿐 아니라, 정서표현에 대한 부정적 신념을 가지게 해 대인관계문제를 더 경험하게 된다고 하였다.

종합하면, 본 연구는 대학생의 성인애착이 대인관계문제에 미치는 영향을 인지적 정서조절 전략이 매개하는지 살펴보았 다. 또한 성인애착의 두 차원인 애착 불안과 애착 회피의 영향 이 차이를 보인다는 선행 연구의 결과에 근거하여, 애착 불안과 애착 회피를 구분하여 모형을 설정한 후 각각의 영향을 살펴보 았다. 각 변인 간 관련성을 탐색한 연구들은 보고되었지만, 성 인애착이 대인관계문제에 영향을 미치는 과정에서 인지적 정 서조절 전략의 역할을 탐색한 연구는 매우 드물어, 본 연구에서 는 이를 살펴봄으로써 애착 불안이나 애착 회피로 대인관계문 제를 호소하고 있는 대학생들에게 도움을 줄 수 있는 방법의 일 환으로 인지적 정서조절 전략의 기능을 밝히고자 하였다. 본 연 구의 연구모형(Figure 1)은 다음과 같다.

\section{연구문제 1}

대학생의 성인애착, 인지적 정서조절 전략 및 대인관계문제 간 상관은 어떠한가?

\section{연구문제 2}

대학생의 성인애착이 대인관계문제에 미치는 영향을 인지적 
정서조절 전략이 매개하는가?

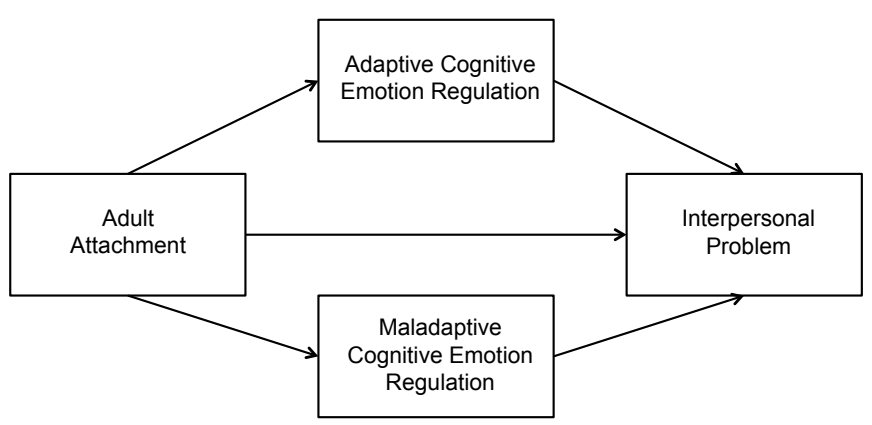

Figure 1. The hypothesized research model.

\section{연구방법}

\section{연구대상}

본 연구의 대상은 대학교에 재학중인 남녀 대학생 300 명이다. 대학생 시기는 입시에 초점이 되었던 중고등학교 시기를 벗어 나 대학이라는 새로운 환경에 적응해나가며 다양한 사람들과 친밀감을 형성해야하는 시기이다(Erikson, 1963, 1980). 따라 서 적응적인 대학생활 및 원활한 관계 형성을 위해서 효과적 인 대인관계의 중요성이 부각되는 시기이기 때문에 이 시기에 속한 대학생들을 본 연구의 연구대상으로 선정하였다.

연구대상자의 사회인구학적 특성을 살펴보면, 성별의 경 우 남학생이 182 명(60.7\%), 여학생이 117 명(39.0\%)으로 남 학생의 비율이 더 높았다. 평균 연령은 20.7 세 $(S D=2.26$ 세 $)$ 였 으며, 1학년 103명(34.3\%), 2학년 104명(34.7\%), 3학년 49명 (16.3\%), 4 학년(이상)이 43 명(14.3\%)이었다. 지역 분포를 살 펴보면 서울과 수도권에 위치한 대학에 다니는 대학생들이 141 명(47.0\%)으로 가장 많았으며, 그 다음으로 충청도 134 명 (44.7\%), 경상도 17 명 $(5.7 \%)$, 강원도 4 명(1.3\%), 전라도 1명 $(0.3 \%)$ 순이었다. 전공계열을 살펴보면, 항공계열을 포함한 기타가 83명(27.7\%)으로 가장 많았고, 공과계열 80명(26.7\%), 사회계열 70명(23.3\%), 인문계열 35명(11.7\%), 예체능계열 10 명(3.3\%), 의약계열 9명(3.0\%), 교육계열 6명(2.0\%), 자연 계열 6 명 $(2.0 \%)$ 순이었다. 부모의 교육수준을 살펴보면 아버 지와 어머니 모두 대학교 졸업이 각각 156 명 (52.0\%)과 141 명(47.0\%)으로 가장 많았으며, 그 다음으로는 고등학교 졸업 이 각각 89 명(29.7\%)과 125 명(41.7\%), 대학원 졸업 각각 43명 (14.3\%)과 20명(6.7\%) 순이었다.

\section{연구도구}

본 연구의 질문지는 성인애착, 인지적 정서조절 전략 및 대인 관계문제를 측정하기 위한 척도들로 구성되어 있으며, 모든 문항은 대학생의 자기보고로 응답되었다.

\section{성인애착}

성인애착은 Brennan, Clark과 Shaver (1998)가 개발하고 Fraley, Waller와 Brennan (2000)이 개정한 '친밀한 관계에서의 경험개정판(Experiences in Close Relationship-Revised [ECR-R])을 Seong-Hyeon Kim (2004)이 번안한 척도를 사용하여 측정하였 다. ECR-R에는 총 36문항이 포함되며, 애착 불안(18문항)과 애착 회피(18문항)의 두 하위요인을 포함한다. 각 요인의 문항 의 예를 살펴보면, 애착 불안의 경우 "때로 다른 사람들은 분 명한 이유 없이 나에 대한 그들의 감정을 바꾸곤 한다." "일단 다른 사람들이 나에 대해 알게 되면, 그들이 있는 그대로의 내 모습을 좋아하지 않을까봐 두렵다.”, “내가 다른 사람들에게 갖는 호감만큼 그들도 내게 강한 호감을 가지기를 자주 원한 다." 등이 있다. 애착 회피에는 "다른 사람들을 의지하는 것이 어렵다.", "다른 사람들과 지나치게 가까워지는 것을 원치 않 는 편이다.", "다른 사람들에게 내 마음속 깊은 감정을 드러내 는 것을 원치 않는 편이다.” 등의 문항들이 포함된다.

각 문항은 전혀 그렇지 않다(1점)에서 매우 그렇다(7점)까 지의 7점 Likert식 척도로 응답하도록 구성하였다. 각 하위 요 인별로 방향성이 다른 문항은 역채점한 후 평균을 산출하였 으며, 점수가 높을수록 그 하위요인의 특성을 더 보이는 것을 의미한다. 각 하위요인별 내적합치도(Cronbach's $\alpha$ )는 애착 불 안 .94, 애착 회피.90이었다.

\section{인지적 정서조절 전략}

인지적 정서조절 전략을 측정하기 위하여 Garnefski 등(2001) 이 개발한 인지적 정서조절 전략 척도(Cognitive Emotion Regulation Questionnaire [CERQ])를 So-Hee Kim (2004)이 번 안한 척도를 사용하였다. CERQ는 총 36문항으로, 적응적 인 지적 정서조절 전략(20문항)과 부적응적 인지적 정서조절 전 략(16문항)으로 구분된다.

적응적 인지적 정서조절 전략에는 조망확대, 계획 다시 생 각하기, 긍정적 초점변경, 수용, 긍정적 재평가와 관련된 문항 들이 포함된다. 각각의 문항의 예를 살펴보면 조망확대는 "나 
는 그 일이 그만하길 다행이라고 생각한다.", 계획 다시 생각 하기는 "그 상황에 대처할 수 있는 최선의 방법을 생각한다.", 긍정적 초점변경은 "내게 일어난 일 대신 다른 즐거운 일을 생 각해본다.”, 수용은 “나는 그 일을 안고 살아가는 법을 배워야 한다고 생각한다.", 긍정적 재평가는 "그 문제의 긍정적인 측 면을 찾아본다.” 등이 있다. 부적응적 인지적 정서조절 전략에 는 자기비난, 타인비난, 반추, 파국화가 포함된다. 각각의 문항 의 예를 살펴보면, 자기비난은 “그 일이 내 잘못이라고 생각한 다.", 타인비난은 “그 일이 일어난 것은 다른 사람의 책임이라 고 생각한다.”, 반추는 “그 상황에서 일어났던 나의 감정을 되 짚어 생각한다.”, 파국화는 "내가 겪은 일이 얼마나 끔찍한지 에 대해 계속 생각한다.” 등이 있다.

각 문항은 전혀 그렇지 않다(1점)에서 매우 그렇다(5점)까 지의 5점 Likert식 척도로 응답되었다. 각 하위요인별로 점수 가 높을수록 적응적 전략을 많이 사용하거나 부적응적인 전략 을 많이 사용하는 것을 의미한다. 각 하위 요인별 내적합치도 (Cronbach's $\alpha$ )는 적응적 인지적 정서조절 전략 .91, 부적응적 인지적 정서조절 전략 .80 이었다.

\section{대인관계문제}

대인관계문제는 Horowitz, Rosenberg, Baer, Ureño와 Villaseñor (1988)가 개발한 대인관계문제 척도(Inventory of Interpersonal Problems [IIP])를 Alden, Wiggins와 Pincus (1990)가 대인관계 문제원형척도(Inventory of Interpersonal Problems-Circumplex scale [IPC-C])로 재구성한 것을 국내에서 Hong 등(2002)이 타 당화한 한국판 대인관계문제원형 척도-단축형(Short form of the Korea Inventory of Interpersonal Problems Circumplex Scale [KIIP-SC])을 사용하여 측정하였다. 원 척도는 비주장성, 과순 응성, 자기희생, 통제지배, 자기중심성, 과관여, 냉담, 사회적 억제의 8 가지의 하위요인으로 구성되어 있으나, 선행연구들 (Ahn, 2012; H. R. Cha, 2016)은 Horney (1946/2006)의 이론을 적용하여 사람들에게 향함(비주장성, 과순응성, 자기희생), 사 람들에게 맞섬(통제지배, 자기중심성, 과관여), 사람들에게서 멀어짐(냉담, 사회적 억제)의 세 하위요인으로 구분하여 사용 하였다. 본 연구에서도 이러한 구분을 사용하여 세 요인으로 구성하여 살펴보았다.

문항의 예를 살펴보면, 사람들에게 향함(15문항)은 “내가 원하는 것을 말하기가 어렵다.”, “다른 사람들에게 정당한 요 구라도 하기 어렵다.", "자기주장이 강한 사람들과 같이 있으 면 내 주장을 내세우기가 어렵다.”와 같은 문항이 포함되며,
사람들에게 맞섬(15문항)은 “다른 사람의 어려움을 보고도 진 심으로 걱정해주기가 어렵다.”, “다른 사람의 입장을 지지해 주기가 어렵다.", "다른 사람의 요구를 먼저 들어주기가 어렵 다.” 등의 문항이 해당된다. 사람들에게서 멀어짐(10문항)은 "친구 사귀기가 어렵다.", "사람들과 어울리기가 어렵다." "다 른 사람에게 애정을 느끼기가 어렵다.", "다른 사람에게 친근 감을 느끼기가 어렵다.”등의 문항을 그 예로 들 수 있다.

각 문항은 전혀 그렇지 않다(1점)에서 매우 그렇다(5점)까 지의 5점 Likert식 척도로 응답하도록 구성되어 있으며, 각 하 위요인별로 점수가 높을수록 대인관계에서 문제를 많이 보이 는 것을 의미한다. 하위요인 별 내적합치도(Cronbach's $\alpha$ )는 사람들에게 향함 .91 , 사람들에게 맞섬 .88 , 사람들에게서 멀 어짐 .91 이었다.

\section{연구절차 및 자료분석}

본 연구의 자료는 2017년 7월부터 8월까지 오프라인 $(N=288)$ 과 온라인 $(N=66)$ 을 통해 설문지를 배포하여 수집하였다. 온 라인을 통하여 수집한 자료는 자발적으로 설문 응답에 동의를 한 대상에 한하여 대학생들이 이용하는 커뮤니티와 소셜 네트 워크 서비스를 이용하여 연구대상자를 모집하였다. 오프라인 설문지는 서울에 위치한 2년제 대학과 충청도에 위치한 4년제 대학에 직접 방문하여 설문 응답에 동의를 한 대상에 한해 수 집되었다. 설문지는 사회인구학적 배경, 성인애착, 대인관계문 제, 인지적 정서조절 전략에 관한 문항 순으로 구성되었으며, 응답에는 10-15분 정도 소요되었다. 최종 수집된 354부 중 불 성실하게 응답했거나(52부), 연구대상 기준에 포함되지 않은 경우(2부)를 제외하고 총 300 부를 최종 분석에 사용하였다.

본 연구에서 수집된 자료는 SPSS 22.0 (IBM Co., Armonk, $\mathrm{NY}$ ) 프로그램을 사용하여 다음과 같은 과정으로 분석하였 다. 첫째, 연구대상의 사회인구학적 특성을 알아보기 위해 빈 도와 백분율을 산출하였다. 둘째, 조사도구의 문항 간 내적합 치도를 살펴보기 위해 Cronbach's $\alpha$ 값을 산출하였다. 셋째, 각 변인 간의 상관관계를 알아보고자 Pearson의 적률상관계 수를 산출하였다. 마지막으로, 대학생의 성인애착이 대인관 계 문제에 미치는 영향에서 인지적 정서조절 전략의 매개효 과를 살펴보기 위하여, 적응적 인지적 정서조절 전략과 부적 응적 인지적 정서조절 전략을 매개변인으로 하는 다중매개모 형을 설정하여 분석하였다. 이를 위해 SPSS PROCESS Macro v3.0 프로그램(Hayes, 2015)을 사용하여 각 매개변인의 효과 가 유의한지 살펴보았다. 간접효과의 유의성은 부트스트랩핑 
Table 1

Correlations Among Adult Attachment, Cognitive Emotion Regulation Strategy, and Interpersonal Problems

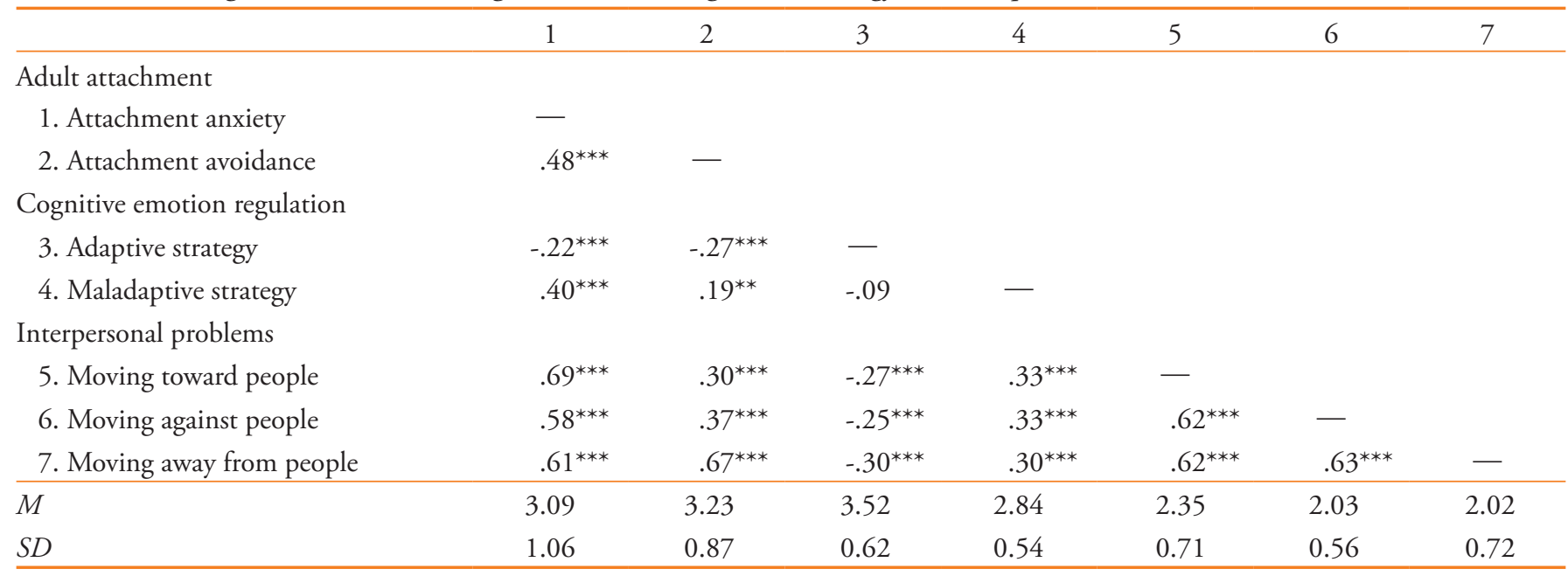

Note. $N=300$.

${ }^{* *} p<.01 .{ }^{* * *} p<.001$.

(bootstrapping) 방법을 통해 확인하였으며, 표본수를 5,000개 로 하고 $95 \%$ 신뢰구간에서 검증하였다.

\section{연구결과}

\section{예비분석}

본 분석에 앞서 대학생의 성별에 따라 성인애착, 인지적 정서 조절 전략 및 대인관계문제에 차이가 있는지 살펴보기 위해 독립표본 $t$ 검정을 실시하였다. 그 결과 모든 변인에서 통계적 으로 유의한 성차가 발견되지 않았다. 따라서 추후 분석은 성 별에 따른 구분 없이 전체를 대상으로 실시하였다.

\section{변인 간 상관관계}

대학생의 성인애착, 인지적 정서조절 전략 및 대인관계문제 간의 상관관계를 살펴보기 위해 Pearson의 적률상관계수를 산 출하였다. 그 결과, 모든 변인들 간에 통계적으로 유의한 상관 이 나타났다(Table 1). 이를 구체적으로 살펴보면, 첫째, 성인 애착의 두 하위요인인 애착 불안과 애착 회피는 대인관계문제 의 모든 하위요인과 정적으로 유의한 상관을 보였다(애착 불 안: $r s=.58 \sim .69, p<.001$, 애착 회피: $r s=.30 \sim .67, p<.001)$. 즉, 애착과 관련된 불안과 회피 수준이 높을수록 대인관계문제를 더 보였다. 둘째, 성인애착과 인지적 정서조절 전략 간 상관을
살펴본 결과, 애착 불안 수준이 높을수록 적응적 인지적 정서 조절 전략은 덜 보이고 $(r=-.22, p<.001)$, 부적응적 인지적 정 서조절 전략은 더 보였다 $(r=.40, p<.001)$. 애착 회피도 이와 유사하게 그 수준이 높을수록 적응적 인지적 정서조절 전략 은 덜 보이고 $(r=-.27, p<.001)$, 부적응적 인지적 정서조절 전 략은 더 보였다 $(r=.19, p<.01)$. 마지막으로, 인지적 정서조절 전략과 대인관계문제 간 상관은 유의하여, 적응적 인지적 정 서조절 전략을 더 보일수록 대인관계문제를 덜 경험하고 $(r s=$ -.25 -.30, $p<.001)$, 부적응적 인지적 정서조절 전략을 더 보 일수록 대인관계문제를 더 경험했다 $(r s=.30 \sim .33, p<.001)$.

\section{성인애착이 대인관계문제에 미치는 영향에서 인지적 정서조절 전략의 매개효과}

성인애착의 하위요인인 애착 불안과 애착 회피가 대인관계문 제에 미치는 영향을 인지적 정서조절 전략이 매개하는지 살펴 보기 위하여 인지적 정서조절 전략의 하위요인인 적응적 인지 적 정서조절 전략과 부적응적 인지적 정서조절 전략을 매개 변 인으로 하는 다중매개모형을 설정하여 분석하였다. 즉, 독립변 인으로 성인애착의 하위변인인 애착 불안과 애착 회피를, 매개 변인으로 적응적 인지적 정서조절 전략과 부적응적 인지적 정 서조절 전략을, 그리고 종속변인으로 대인관계문제를 설정하 여 분석하였다. 독립변인인 성인애착의 경우 애착 불안과 애착 회피의 특성이 다르기 때문에 대인관계에 미치는 영향에도 차 이가 있다는 선행 연구의 결과들(Kang \& Choi, 2011; Mikulincer 
Table 2

Cognitive Emotion Regulation Strategies as Mediators of the Relationship Between Attachment Anxiety and Interpersonal Problem

\begin{tabular}{|c|c|c|c|c|c|c|c|}
\hline & & Pathways & $B$ & $S E$ & $t$ & $R^{2}$ & $F\left(d f_{1}, d f_{2}\right)$ \\
\hline \multicolumn{8}{|l|}{ Total effect } \\
\hline Attachment anxiety & $\rightarrow$ & Interpersonal problem (c) & .39 & .02 & $18.52^{* * *}$ & .54 & $343.07^{* * *}(1,298)$ \\
\hline Attachment anxiety & $\rightarrow$ & Adaptive strategy & -.13 & .03 & $-3.90^{* * *}$ & .05 & $15.20^{* * *}(1,298)$ \\
\hline Attachment anxiety & $\rightarrow$ & Maladaptive strategy & .20 & .03 & $7.61^{* * *}$ & .16 & $57.88^{* * *}(1,298)$ \\
\hline Adaptive strategy & $\rightarrow$ & Interpersonal problem & -.15 & .04 & $-4.03^{* * *}$ & & \\
\hline Maladaptive strategy & $\rightarrow$ & Interpersonal problem & .10 & .04 & $2.22^{*}$ & .57 & $128.69^{* * *}(3,296)$ \\
\hline Attachment anxiety & $\rightarrow$ & Interpersonal problem (c') & .35 & .02 & $15.43^{* * *}$ & & \\
\hline
\end{tabular}

Note. $\mathrm{c}=$ A total effect of an independent variable without mediators; c' = A direct effect of an independent variable with mediators. ${ }^{*} p<.05 .{ }^{* * *} p<.001$.

et al., 2003; Shin, 2006; Wei et al., 2005)에 근거하여 각각을 분리 하여 매개모형을 설정하였다. 반면 대인관계문제의 세 하위요 인인 사람들에게 향함, 사람들에게 맞섬, 사람들로부터 멀어짐 의 경우 서로 높은 상관을 보였으며 $(r s=.62 \sim .63, p<.001)$, 전 체 문항을 대상으로 산출한 내적일관도 $(\alpha=.95)$ 도 높아 각각을 종속변인으로 분리하여 분석하는 대신 세 하위요인의 평균값 을 산출하여 단일 변인으로 모형에 포함하였다.

다중매개모형에서 매개효과를 검증하기 위해서는 Preacher 와 Hayes (2008)가 제안한 세 가지 조건이 충족되어야 한다. 첫 째, 독립변인에서 매개변인으로 가는 경로(a), 매개변인이 종속 변인으로 가는 경로(b), 매개변인이 없을 때 독립변인에서 종 속변인으로의 경로(c)가 통계적으로 유의해야한다. 둘째, 종속 변인을 설명하기 위해 독립변인과 매개변인이 함께 모형에 포 함되었을 때 독립변인이 종속변인을 설명하는 직접효과의 크 기(c')가 매개변인이 없을 때의 총 효과(c)에 비해 유의하게 감 소해야 한다. 마지막으로, 매개효과의 유의도를 부트스트랩핑 방식으로 검증한 간접효과의 크기 $(\mathrm{ab})$ 가 통계적으로 유의해야 한다. 간접효과의 유의성을 확인하기 위해 표본 수 5,000번을 재추출하는 부트스트랩핑 방법을 실시하였으며, $95 \%$ 신뢰구 간을 설정하여 검증하였다. 즉, 간접효과의 추정치에 대한 신 뢰구간이 0 을 포함하고 있지 않다면 간접효과가 $\alpha=.05$ 수준 에서 통계적으로 유의한 것으로 결론지을 수 있다.

\section{애착 불안이 대인관계문제에 미치는 영향에서} 인지적 정서조절 전략의 매개효과

애착 불안이 대인관계문제에 미치는 영향이 인지적 정서조
절 전략에 의해 매개되는지 살펴본 결과는 Table 2 와 Figure 2 에 제시하였다. 먼저 애착 불안이 대인관계문제에 미치는 직 접적 영향은 유의하여 $(B=.35, p<.001)$, 애착과 관련한 불안 수준이 높을수록 대인관계문제를 더 경험하였다. 다음으로 간 접적 경로를 살펴보면, 애착 불안에서 적응적 인지적 정서조 절 전략 $(B=-.13, p<.001)$ 과 부적응적 인지적 정서조절 전략 $(B=.20, p<.001)$ 으로의 경로는 유의하여, 애착 불안이 높을 수록 적응적 인지적 정서조절 전략을 더 적게 사용하고, 부적 응적 인지적 정서조절 전략을 더 많이 사용하였다. 인지적 정 서조절 전략에서 대인관계문제로의 경로 또한 유의하여, 적응 적 인지적 정서조절 전략을 많이 사용할수록 대인관계문제 수 준이 낮았고 $(B=-.15, p<.001)$, 부적응적 인지적 정서조절 전 략을 많이 사용할수록 대인관계문제 수준이 높았다 $(B=.10, p$ $<.05)$.

인지적 정서조절 전략의 매개효과와 관련하여, 매개변인 이 포함되지 않았을 때의 총효과는 $.39(p<.001)$ 로 매개변인 이 포함된 후.35 $(p<.001)$ 로 감소하였으며, 설명력은 $54 \%$ 에 서 $3 \%$ 증가하여 $57 \%$ 이었다. 따라서 인지적 정서조절 전략은 애착 불안이 대인관계문제에 미치는 영향을 부분 매개하였다. 이러한 부분 매개효과가 통계적으로 유의한지 살펴보기 위하 여 부트스트랩핑 방법을 사용한 결과, 적응적 및 부적응적 인 지적 정서조절 전략의 매개효과 모두 $95 \%$ 신뢰구간에서 0 을 포함하고 있지 않아 $\alpha=.05$ 수준에서 유의하였다(적응적: $B=$ $.02,95 \%$ 신뢰구간 $=[.0081, .0352]$, 부적응적: $B=.02,95 \%$ 신 뢰구간 $=[.0038, .0406])$. 즉, 인지적 정서조절 전략의 두 하위 요인은 애착 불안이 대인관계문제에 미치는 영향을 부분 매개 하였으며, 이러한 매개효과는 통계적으로 유의하였다. 


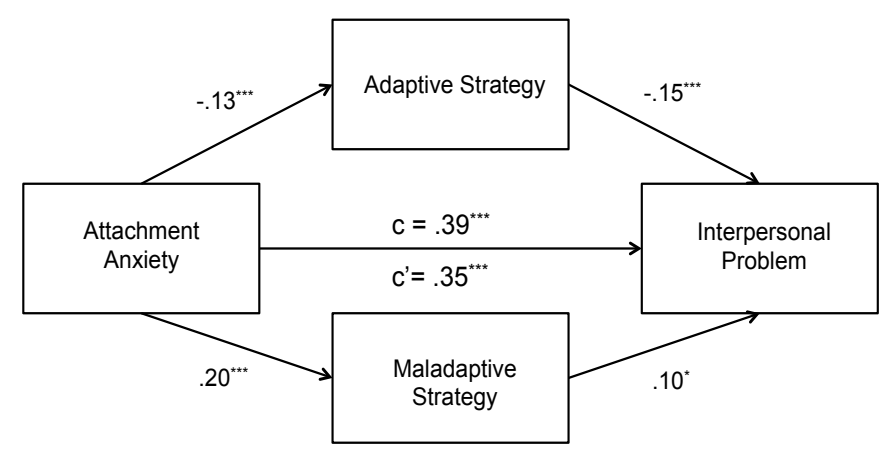

Figure 2. Cognitive emotion regulation strategies as mediators of the relationship between attachment anxiety and interpersonal problem.

${ }^{*} p<.05 .{ }^{* * *} p<.001$.

애착 회피가 대인관계문제에 미치는 영향에서 인지적 정서조절 전략의 매개효과

애착 회피가 대인관계문제에 미치는 영향을 인지적 정서조절 전략이 매개하는지 살펴본 결과는 Table 3과 Figure 3에 제시하 였다. 우선 애착 회피가 대인관계문제에 미치는 직접적 영향 을 살펴보면, 애착 회피가 대인관계문제에 유의하게 영향을 미쳐 $(B=.25, p<.001)$, 애착 회피가 높을수록 대인관계문제 를 많이 지각하는 것으로 나타났다. 그 다음으로 간접적 경로 를 살펴보면, 애착 회피에서 적응적 인지적 정서조절 전략 $(B$ $=-.19, p<.001)$ 과 부적응적 인지적 정서조절 전략 $(B=.12, p<$ .001)으로의 경로는 각각 유의하여, 애착 회피가 높을수록 적 응적 인지적 정서조절 전략은 더 적게 사용하고, 부적응적 인 지적 정서조절 전략은 더 많이 사용하였다. 또한 적응적 인지
적 정서조절 전략 $(B=-.17, p<.001)$ 과 부적응적 인지적 정서 조절 전략 $(B=.30, p<.001)$ 모두 대인관계문제에 유의한 영 향을 미쳤다. 즉, 적응적 인지적 정서조절 전략을 많이 사용할 수록 대인관계문제 수준이 낮았고, 부적응적 인지적 정서조절 전략을 많이 사용할수록 대인관계문제 수준이 더 높았다.

인지적 정서조절 전략의 매개효과를 살펴보면, 애착 회피 가 대인관계문제에 영향을 미치는 총 효과는 .32 ( $p<.001)$ 로 설명력은 $24 \%$ 였으며, 매개변인이 함께 투입되었을 경우 $.25(p<.001)$ 로 그 계수가 감소하였고 설명력은 $11 \%$ 증가하 여 $35 \%$ 였다. 즉, 애착 회피가 대인관계문제에 미치는 영향을 인지적 정서조절 전략이 부분 매개하였다. 매개효과가 통계적 으로 유의한지 살펴보기 위해 부트스트랩핑 방법을 사용한 결 과, 애착 회피가 적응적 인지적 정서조절 전략 $(B=.03,95 \%$ 신

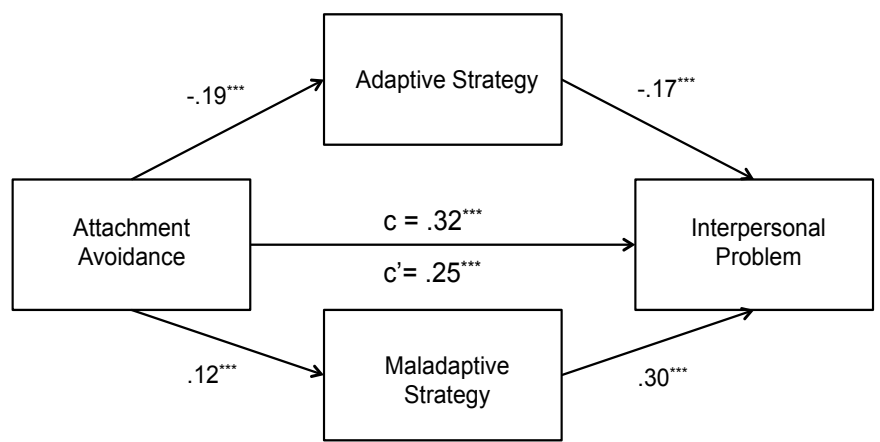

Figure 3. Cognitive emotion regulation strategies as mediators of the relationship between attachment avoidance and interpersonal problem.

${ }^{* * *} p<.001$.

Table 3

Cognitive Emotion Regulation Strategies as Mediators of the Relationship Between Attachment Avoidance and Interpersonal Problem

Pathways

Total effect

Attachment avoidance $\rightarrow$ Interpersonal problem (c)

Independent variable on mediators

Attachment avoidance $\rightarrow$ Adaptive strategy

Attachment avoidance $\rightarrow$ Maladaptive strategy

Independent variable and mediators on dependent variable

Adaptive strategy $\quad \rightarrow \quad$ Interpersonal problem

Maladaptive strategy $\rightarrow$ Interpersonal problem

Attachment avoidance $\rightarrow$ Interpersonal problem (c')

$B \quad S E$

$t$

$R^{2}$

$F\left(d f_{1}, d f_{2}\right)$

$\begin{array}{lllll}.32 & .03 & 9.68^{* * *} & .24 & 93.66^{* * *}(1,298)\end{array}$

$\begin{array}{llll}-.19 & .04 & -4.88^{* * *} & .07 \\ .12 & .04 & 11.40^{* * *} & .04\end{array}$

$23.79^{* * *}(1,298)$

$\begin{array}{llll}.12 & .04 & 11.40^{* * *} \quad .04\end{array}$

$11.40^{* * *}(1,298)$

$\begin{array}{lll}-.17 & .05 & -3.74^{* * *}\end{array}$

$.30 \quad .05 \quad 5.92^{* * *}$

$.25 \quad .03 \quad 7.79^{* * *}$


뢰구간 $=[.0146, .0588]$ 과 부적응적 인지적 정서조절 전략 $(B=$ $.04,95 \%$ 신뢰구간 $=[.0145, .0664])$ 을 통한 효과 각각은 $95 \%$ 신뢰구간에서 0 을 포함하고 있지 않아 $\alpha=.05$ 수준에서 유의 하였다.

\section{논의 및 결론}

본 연구는 남녀 대학생을 대상으로 성인애착이 대인관계문 제에 미치는 영향에서 인지적 정서조절 전략의 매개적 역할 을 살펴보았다. 성인애착의 두 가지 하위 차원인 애착 불안과 애착 회피는 그 특성이 다를 수 있기 때문에(Mikulincer et al., 2003; Wei et al., 2005), 애착 불안과 애착 회피로 분리하여 모 형을 설정한 후 분석하였다. 본 연구의 연구문제를 중심으로 그 결과를 요약하고 논의하면 다음과 같다.

첫째, 성인애착이 대인관계문제에 미치는 영향과 관련하 여, 성인애착의 하위변인인 애착 불안과 애착 회피는 대인관 계문제에 유의한 영향을 미쳤다. 즉, 애착 불안 및 애착 회피 수준이 높을수록 대학생은 대인관계문제를 더 많이 경험하였 다. 이러한 결과는 불안정 애착을 형성할수록 대인관계문제를 더 경험한다고 보고한 선행연구들(Bartholomew \& Horowitz, 1991; Collins \& Read, 1990; Feeney \& Noller, 1990; Haggerty et al., 2009; J. U. Kim \& Yang, 2014; Mikulincer et al., 2003; Moon, 2005; Wei et al., 2005)과 일치하는 것으로, 불안정한 애착을 형 성한 사람들이 타인에 대해 낮은 신뢰를 가지고 있으며, 관계 에 두려움을 더 많이 느끼기 때문에 대인관계를 형성하고 유 지하는데 더 많은 어려움을 경험한다는 것을 알 수 있다.

애착 불안과 애착 회피가 대인관계문제에 미치는 영향을 비교한 결과, 애착 불안이 애착 회피보다 대인관계문제에 더 큰 영향을 미치는 것으로 나타났다. 즉, 애착 불안과 애착 회 피 모두 대인관계문제에 영향을 미쳤지만, 애착 불안 수준 이 높을 경우 대인관계문제의 수준이 더 높았다. 이러한 결과 는 애착 불안과 애착 회피 각각이 가지고 있는 고유한 특성 의 차이로 인해 그 영향에도 차이가 있는 것으로 보고한 선행 연구들(Kang \& Choi, 2011; J. U. Kim \& Yang, 2014; J.-H. Lee \& Shim, 2007; Mikulincer et al., 2003; Park \& Lee, 2010; Wei et al., 2005)의 결과와 유사한 맥락에서 해석할 수 있다. 또한 애 착 불안은 대인관계문제(J. U. Kim \& Yang, 2014; Park \& Lee, 2010)와, 애착 회피는 낮은 대인관계능력(Kang \& Choi, 2011) 과 더 밀접한 연관성이 있는 것으로 나타난 결과와도 유사하 다. 이러한 결과는 애착 불안이 높은 경우 대인관계능력 자
체의 결함을 가지기 보다는 관계를 유지하는 데 어려움을 겪 어 대인관계에서 현재 경험하고 있는 문제를 더 지각하지만, 애착 회피가 높은 경우 다른 사람들에게 소속되기를 회피하 고 겉도는 특징이 있어 대인관계능력 자체가 낮은 것과 더 큰 연관성을 지니기 때문인 것으로 해석할 수 있다(Park \& Lee, 2010). 이러한 가능성을 탐색해 보기 위해서는 대인관계문제 와 대인관계능력을 함께 측정하는 후속 연구를 통해 애착 불 안과 애착 회피가 대인관계문제와 대인관계능력에 각기 다른 영향을 미치는지 탐색해 볼 필요가 있다.

둘째, 대학생의 성인애착이 인지적 정서조절 전략에 미치 는 영향은 유의하여, 애착 불안과 애착 회피 수준이 높을수록 대학생들은 적응적 인지적 정서조절 전략은 덜 보이고, 부적 응적 인지적 정서조절 전략을 더 사용하였다. 이러한 결과는 선행연구들(Jeon \& Hong, 2012; J.-Y. Kim, 2016; Shin, 2006)의 결과와 일치하는 것으로, 애착 불안과 애착 회피 수준이 높을 수록 스트레스 상황에서 긍정적으로 초점을 바꾸어 생각하거 나 그 상황을 받아들이며 정서를 조절하기 보다는 그 상황을 계속해서 반추하거나 자기 또는 타인을 비난하는 등 자신의 부정적인 정서를 적응적으로 조절하는데 어려움을 경험한다 는 것을 시사한다. 또한 애착 불안과 애착 회피 모두 인지적 정 서조절 전략에 유의한 영향을 미쳤지만, 애착 불안이 애착 회 피보다 적응적 인지적 정서조절 전략과 부적응적 인지적 정서 조절 전략 모두에 상대적으로 더 큰 영향을 미치는 것으로 나 타났다. 이러한 차이는 애착 회피의 특성과 관련해서 해석해 볼 수 있는데, 애착 회피가 높을 경우 스트레스 상황에서 전략 을 사용하여 이를 해결하기 위해 노력하기보다는 인지 - 행동 적으로 거리를 두고 회피하거나 외면하는 특성이 있기 때문일 수 있다(Shaver \& Mikulincer, 2002; Wei et al., 2005). 즉, 애착 회피 수준이 높을 경우 전략 자체를 덜 사용하기 때문에 그 영 향력이 덜 했을 가능성이 있다.

셋째, 인지적 정서조절 전략이 대인관계문제에 미치는 영 향과 관련하여, 적응적 인지적 정서조절 전략을 많이 사용할 수록 대인관계문제 수준은 낮아지고, 부적응적인 정서조절 전 략을 많이 사용할수록 대인관계문제 수준은 높아졌다. 이는 애착 불안과 애착 회피 모형 모두에서 유사하게 나타났다. 이 러한 결과는 부적응적인 인지적 정서조절 전략을 많이 사용할 수록 대인관계문제의 모든 하위영역 수준이 높아졌다고 보고 한 연구(M. J. Kim, 2010)와 적응적, 부적응적 인지적 정서조 절 전략이 대인관계문제에 영향을 미치는 것으로 보고한 연구 (E.-Y. Kim, 2009)와 일치한다. 또한 대인관계문제는 아니지만 이와 밀접한 관련이 있는 것으로 보고된 사회성에 인지적 정 
서조절 전략이 미치는 영향을 보고한 연구(Mikolajczak et al., 2008)의 결과와도 맥을 같이 한다. 이를 통해 대인관계를 형성 하고 유지할 때 경험하는 어려움들은 자신의 정서를 적응적으 로 조절하는 능력, 즉 부정적인 상황에서 긍정적인 부분에 초 점을 맞추어 정서를 조절하는 긍정적 재평가, 부정적인 감정 에 매몰되지 않고 긍정적인 일을 생각하며 정서를 조절하는 긍정적 초점변경, 다른 부정적인 일들과 비교하여 현재 상황 이 나쁘지만은 않다고 생각하는 조망확대, 앞으로 비슷한 부 정적인 상황이 일어났을 때 어떻게 대처할지 계획해보는 계획 다시 생각하기 등과 같은 적응적인 전략을 훈련하는 것을 통 해 예방할 수 있을 것으로 보인다.

마지막으로, 대학생의 성인애착이 대인관계문제에 미치는 영향에서 인지적 정서조절 전략의 매개 효과를 살펴본 결과, 인지적 정서조절 전략은 애착 불안과 애착 회피가 대인관계문 제에 미치는 영향을 부분 매개하였다. 즉, 애착 불안과 애착 회 피 수준이 높을수록 대인관계문제에 직접적으로 부정적인 영 향을 미쳤을 뿐 아니라, 인지적으로 적응적인 정서조절 전략 을 효율적으로 사용하지 못하여 그 결과, 대인관계에서 더 많 은 문제를 경험하였다. 이러한 결과는 성인애착과 대인관계 유능성 간의 관계에서 인지적 정서조절 전략 또는 정서조절 의 매개효과를 발견한 선행연구들(J.-Y. Kim, 2016; Shin, 2006) 이나 성인애착이 정서조절곤란을 매개로 대인관계문제에 부 정적인 영향을 미치는 것으로 보고한 연구(D.-W. Lee, 2015)의 결과와 유사하다. 이를 통해 불안정 애착을 경험하고 있는 대 학생들의 경우 정서 인식, 표현 및 조절에 있어서 어려움을 겪 어, 대인관계문제까지도 영향을 받는다는 것을 알 수 있다. 인 지적 정서조절 전략의 매개적 역할을 밝힌 본 연구의 결과는 특히 상담 현장에서 유용하게 활용될 수 있는데, 애착과 관련 된 불안이나 회피 수준이 높은 대학생들이 경험하는 대인관계 문제를 완화하기 위해서는 부정적인 정서가 촉발될 수 있는 상황에서 이를 적응적인 방식으로 조절할 수 있도록 개입하는 것이 도움이 될 것으로 보인다. 이를 위해 대학생들의 현재 애 착 상태를 파악하고, 불안정 애착 수준이 높은 대학생들을 대 상으로 하는 개인 상담 또는 집단 교육 및 상담 장면에서 인지 적 정서조절을 시도할 수 있도록 교육과 훈련을 통해 개입을 시도하는 것이 대인관계에서의 문제를 해결하는 데 도움이 될 것으로 보인다. 즉, 대학생 내담자의 상담 내용에서 자기비난, 타인비난, 반추 등과 같은 부적응적인 조절 방식이 반복해서 나타날 경우, 상담자는 적응적 인지적 정서조절 전략에 해당 하는 조망확대, 계획 다시 생각하기, 긍정적 초점 변경, 수용, 긍정적 재평가 등으로 인지를 변화시킬 수 있도록 훈련의 기
회를 제공함으로써 궁극적으로는 대인관계에서 경험하는 어 려움을 경감시킬 수 있도록 개입할 수 있을 것이다.

본 연구의 제한점과 이를 토대로 후속 연구에 대한 제언을 하면 다음과 같다. 첫째, 본 연구는 서울 지역의 2 년제 대학교, 충청도 지역의 4 년제 대학교 각각 1 곳과 서울 및 경기도, 전라 도, 경상도, 강원도 등의 대학에 재학 중인 대학생들을 대상으 로 실시하였는데, 서울 및 충청도 지역을 제외한 나머지 지역 의 경우 표본 수가 많지 않아 결과를 일반화하기에 어려움이 있다. 따라서 이후 연구에서는 결과를 일반화할 수 있도록 지 역별, 대학별로 풍부한 표본을 수집할 필요가 있다. 둘째, 본 연구에서는 전체 대학생을 대상으로 연구를 진행하였는데, 대 학생들 중 대학에 막 진학한 1학년이나 취업을 앞두고 있는 4 학년과 같이 신입생, 취업준비생 또는 휴학생, 복학생, 군 입 대를 한 대학생 등 대학생이 현재 처해 있는 상황에 따라 대인 관계문제를 다르게 지각하고 있을 가능성이 있다. 따라서 후 속 연구에서는 대상을 세분화하여 각각의 특성을 살펴보는 것 도 흥미로울 것이다. 셋째, 본 연구에서는 전반적인 관계에서 가지는 애착으로 성인애착을 측정하였다. 하지만 최근 대상에 따라 차별적인 성인애착 패턴이 형성될 수 있다는 주장들 $(\mathrm{Jo}$ \& Seo, 2010; J. Kim \& Lee, 2015)이 나타나고 있다. 특히 성인 초기인 대학생 시기는 애착 대상의 전환이 다양하게 이루어지 는 시기이므로, 활성화된 표상이 누구인지에 따라 애착 패턴 도 변화할 가능성이 있다(K. U. Kim, 2005). 따라서 성인애착 을 애착 대상별로 구분하여 그 차이를 살펴보는 것도 후속 연 구의 주제가 될 수 있을 것이다.

이와 같은 제한점에도 불구하고 본 연구는 다음과 같은 의 의를 가진다. 첫째, 본 연구는 성인애착의 하위변인인 애착 불 안과 애착 회피가 대인관계문제에 미치는 영향에서 적응적, 부적응적 인지적 정서조절 전략의 매개효과를 각각 살펴봄으 로써 기존의 성인애착과 대인관계 간의 관련성을 살펴본 연구 들을 확장하였다는 데 의의가 있다. 애착 불안과 애착 회피가 서로 다른 특성을 지니고 있어, 인지적 정서조절 전략과 대인 관계문제에 모두 유의한 영향을 미쳤지만, 그 영향력에는 다 소 차이가 있음을 확인할 수 있었다. 둘째, 본 연구의 결과는 대인관계문제를 경험하고 있는 대학생들에게 보다 개입이 용 이한 인지적 정서조절 전략을 교육하여 대인관계에서의 어려 움을 낮추도록 돕는데 활용될 수 있다. 다시 말하면 성인애착 으로 인하여 대인관계문제를 경험하고 있는 대학생들에게 여 러 가지 방법 중 하나로서 인지적 정서조절 전략을 증진시킬 수 있도록 조력할 수 있을 것이다. 본 연구가 대학생들의 긍정 적이고 적응적인 대학생활과 삶을 영위할 수 있도록 하는 기 
초자료이자 토대가 되기를 기대한다.

\section{Acknowledgements}

This work was supported by the Ministry of Education of the Republic of Korea and the National Research Foundation of Korea (NRF-2016S1A3A2924375).

\section{Notes}

This article is a part of the first author's master's thesis submitted in 2018 and was presented at the 2018 Annual Spring Conference of the Korean Association of Child Studies.

\section{Conflict of Interest}

No potential conflict of interest relevant to this article was reported.

\section{References}

\section{In English}

Alden, L. E., Wiggins, J. S., \& Pincus, A. L. (1990). Construction of circumplex scales for the Inventory of Interpersonal Problems. Journal of Personality Assessments, 55(3-4), 521536. doi:10.1080/00223891.1990.9674088

Arnett, J. J. (2000). Emerging adulthood: A theory of development from the late teens through the twenties. American Psychologist, 55(5), 469-480. doi:10.1037/0003-066X.55.5.469

Bartholomew, K., \& Horowitz, L. M. (1991). Attachment styles among young adults: A test of a four-category model. Journal of Personality and Social Psychology, 61(2), 226-244. doi:10. 1037/0022-3514.61.2.226

Bowlby, J. (1969/1982). Attachment and loss: Vol 1. Attachment (2nd ed.). New York: Basic Books.

Bowlby, J. (1973). Attachment and loss: Vol 2. Separation. New York: Basic Books.

Brennan, K. A., Clark, C. L., \& Shaver, P. R. (1998). Self-report measurement of adult romantic attachment: An integrative overview. In J. A. Simpson \& W. S. Rholes (Eds.), Attachment theory and close relationships (pp. 46-76). New York: Guilford Press.

Cassidy, J., \& Kobak, R. R. (1988). Avoidance and its relationship with other defensive processes. In J. Belsky \& T. Nezworski (Eds.), Clinical implications of attachment (pp.300-323). Hillsdale, NJ: Erlbaum.

Collins, N. L., \& Read, S. J. (1990). Adult attachment, working models and relationship quality in dating couples. Journal of Personality and Social Psychology, 58(4), 644-663. doi:10.1037/0022-3514.58.4.644

Erikson, E. H. (1963). Childhood and society. New York: Norton.

Erikson, E. H. (1980). Identity and the life cycle. New York: Norton.

Feeney, J. A., \& Noller, P. (1990). Attachment style as a predictor of adult romantic relationships. Journal of Personality and Social Psychology, 58(2), 281-291. doi:10.1037/00223514.58.2.281

Fraley, R. C., \& Waller, N. G. (1998). Adult attachment patterns: A test of the typological model. In J. A. Simpson \& W. S. Rholes (Eds.), Attachment theory and close relationships (pp. 77-114). New York: Guilford Press.

Fraley, R. C., Waller, N. G., \& Brennan, K. A. (2000). An item response theory analysis of self-report measures of adult attachment. Journal of Personality and Social Psychology, 78(2), 350-365. doi:10.1037/0022-3514.78.2.350

Garnefski, N., \& Kraaij, V. (2007). The cognitive emotion regulation questionnaire. European Journal of Psychological Assessment, 23(3), 141-149. doi:10.1027/1015-5759.23.3. 141

Garnefski, N., Kraaij, V., \& Spinhoven, P. (2001). Negative life events, cognitive emotion regulation and emotional problems. Personality and Individual Differences, 30(8), 1311-1327. doi:10.1016/S0191-8869(00)00113-6

Garnefski, N., Legerstee, J., Kraaij, V., van den Kommer, T., \& Teerds, J. (2002). Cognitive coping strategies and symptoms of depression and anxiety: A comparison between adolescents and adults. Journal of Adolescence, 25(6), 603-611. doi:10.1006/jado.2002.0507

Gross, J. J. (1998). The emerging field of emotion regulation: An integrative review. Review of General Psychology, 2(3), 271299. doi:10.1037/1089-2680.2.3.271

Haggerty, G., Hilsenroth, M. J., \& Vala-Stewart, R. (2009). Attachment and interpersonal distress: Examining the relationship between attachment styles and interpersonal problems in a clinical population. Clinical Psychology \& Psychotherapy, 16(1), 1-9. doi:10.1002/cpp.596

Hayes, A. F. (2015). The PROCESS macro for SPSS and SAS [Computer software]. Retrieved from http://www. processmacro.org

Horney, K. (2006). Our inner conflicts (H. K. Lee, I. Yoon, H. R. Lee, \& H. I. Cho, Trans.). Seoul: Hakjisa. (Original work published 1946).

Horowitz, L. M., Rosenberg, S. E., Baer, B. A., Ureño, G., \& 
Villaseñor, V. S. (1988). Inventory of interpersonal problems: Psychometric properties and clinical applications. Journal of Consulting and Clinical Psychology, 56(6), 885892. doi:10.1037/0022-006X.56.6.885

Hwang, J. (2006). A processing model of emotion regulation: Insights from the attachment system (Doctoral dissertation). Retrieved from https://scholarworks.gsu.edu/cgi/viewcontent. cgi? referer=http://scholar.google.co.kr/\&httpsredir=1\&artic le $=1013 \&$ context $=$ psych_diss

John, O. P., \& Gross, J. J. (2004). Healthy and unhealthy emotion regulation: Personality processes, individual differences, and life span development. Journal of Personality, 72(6), 13011334. doi:10.1111/j.1467-6494.2004.00298.x

Main, M., Kaplan, K., \& Cassidy, J. (1985). Security in infancy, childhood and adulthood: A move to the level of representation. In I. Bretherton \& E. Waters (Eds.), Growing points of attachment theory and research. Chicago, IL: University of Chicago Press.

Mikolajczak, M., Nelis, D., Hansenne, M., \& Quoidbach, J. (2008). If you can regulate sadness, you can probably regulate shame: Associations between trait emotional intelligence, emotion regulation and coping efficiency across discrete emotions. Personality and Individual Differences, 44(6), 1356-1368. doi:10.1016/j.paid.2007.12.004

Mikulincer, M., Shaver, P. R., \& Pereg, D. (2003). Attachment theory and affect regulation: The dynamics, development, and cognitive consequences of attachment-related strategies. Motivation and Emotion, 27(2), 77-102. doi:10.1023/ A: 1024515519160

Preacher, K. J., \& Hayes, A. F. (2008). Asymptotic and resampling strategies for assessing and comparing indirect effects in multiple mediator models. Behavior Research Methods, 40(3), 879-891. doi:10.3758/BRM.40.3.879

Shaver, P. R., \& Mikulincer, M. (2002). Attachment-related psychodynamics. Attachment \& Human Development, 4(2), 133-161. doi:10.1080/14616730210154171

Teyber, E. (2000). Interpersonal process in psychotherapy: A relational approach. Stamford, CT: Wadsworth Publishing Company.

Wei, M., Vogel, D. L., Ku, T.-Y., \& Zakalik, R. A. (2005). Adult attachment, affect regulation, negative mood, and interpersonal problems: The mediating roles of emotional reactivity and emotional cutoff. Journal of Counseling Psychology, 52(1), 14-24. doi:10.1037/0022-0167.52.1.14

\section{In Korean}

Ahn, E. H. (2012). The effect of separation-individuation in university students on interpersonal problems: The mediating effect of automatic thoughts (Master's thesis). Retrieved from http://www.riss.kr/link?id=T12851493
Cha, H. R. (2016). The effects of internalized shame on interpersonal problems: The mediating effects of rejection sensitivity and the moderating effects of cognitive emotion regulation (Master's thesis). Retrieved from http://www.riss.kr/link?id=T14151382

Cha, J. E. (2016). The effect of university students' adult attachment on interpersonal relationships: Mediating effect of emotional regulation and the negative beliefs in emotional expression (Master's thesis). Retrieved from http://www.riss.kr/link?id=T14047746

Ha, J.-H., \& Jo, H.-I. (2006). The relationships among perfectionism, stress, the ways of stress coping, self-efficacy, college adjustment. The Korea Journal of Counseling, 7(2), 595-611.

Hong, S.-H., Park, E.-Y., Kim, Y.-H., Kwon, J.-H., Cho, Y., \& Kim, Y. (2002). Short form of the Korean Inventory of Interpersonal Problems Circumplex Scales (KIIP-SC). Korean Journal of Clinical Psychology, 21(4), 923-940.

Jeon, E.-S., \& Hong, H.-Y. (2012). The moderating effects of cognitive emotion regulation strategies on the relationship of between adult attachment and forgiveness. Korean Journal of Counseling, 13(3), 1159-1179.

Jo, H. J., \& Seo, Y. S. (2010). Parental attachment, separationindividuation, adult attachment, college adjustment, and psychological distress among college freshmen. The Korean Journal of Counseling and Psychotherapy, 22(2), 385-411.

Kang, S.-J., \& Choi, Y.-H. (2011). The influence of adult attachment on interpersonal abilities: The intermediate effect of emotion regulation style and social anxiety. The Korean Journal of the Human Development, 18(3), 53-68.

Kim, E.-Y. (2009). The relationships between emotional clarity and interpersonal problems: The mediation effect of cognitive emotion regulation (Master's thesis). Retrieved from http:// www.riss.kr/link?id=T11732825

Kim, J., \& Lee, J. (2015). Adult attachment styles across close relationships among Korean college students: A latent profile analysis. Journal of Korean Home Management Association, 33(4), 119-145.

Kim, J. U., \& Yang, M. J. (2014). The influences of attachment and self-efficacy on interpersonal problems of college students. Journal of Learner-Centered Curriculum and Instruction, 14(2), 283-299.

Kim, J.-Y. (2016). The mediating effects of cognitive emotion regulation in relation between adult attachment and interpersonal competence among undergraduates (Master's thesis). Retrieved from http://www.riss.kr/link?id=T14180885

Kim, K. U. (2005). Stability in adult attachment and its relation with cadet's early phase adaptation. The Korean Journal of Counseling and Psychotherapy, 17(2), 485-501.

Kim, M. J. (2010). Influences of self-differentiation and cognitive emotion regulation strategies on interpersonal problems (Master's thesis). Retrieved from http://www.riss.kr/link?id=T12130230

Kim, N.-M., \& Kim S.-S. (2013). Mediation effects of social 
support and resilience between life stress and psychological well-being among Korean college students. Korean Journal of Counseling, 14(2), 1125-1144.

Kim, Seong-Hyeon. (2004). Adaptation of the Experiences in Close Relationships-Revised Scale into Korean: Confirmatory factor analysis and item response theory approaches (Master's thesis). Retrieved from http://www.riss.kr/link?id=T9328715

Kim, So-Hee. (2004). A study on relationships among the stressful events, cognitive emotion regulation strategies and psychological well-being (Master's thesis). Retrieved from http://www.riss. $\mathrm{kr} /$ link?id=T9560970

Kim, S.-H., \& Kim, J.-W. (2004). Relationships among psychological separation, interpersonal relation dispositions and social adjustment. The Korean Journal of Educational Psychology, 18(2), 83-97.

Lee, D.-W. (2015). The mediating effect of difficulties in emotional regulation in relation between adult attachment and interpersonal problems among undergraduates (Master's thesis). Retrieved from http://www.riss.kr/link?id=T13865675

Lee, J.-H., \& Sim, H.-S. (2007). A analysis of covariance structure of interpersonal relationships by the adult attachment. The Korean Journal of Counseling, 8(3) 899-915.
Moon, H. J. (2005). The study on the levels of interpersonal relationship problem according to adult attachment and selfconsciousness style. Study on Student's Life, 27, 5-38.

Park, Y. J., \& Lee, Y. H. (2010). The effects of anxious attachment and avoidant attachment on interpersonal problems: The mediation effects of depressive experience styles. The Korean Journal of Clinical Psychology, 29(2), 441-452.

Shin, J. W. (2006). The path analysis of the relationship of attachment, emotion, and interpersonal competence (Master's thesis). Retrieved from http://www.riss.kr/link?id=T10532457

\section{Du Ri Kwon http://orcid.org/0000-0003-0972-1237 \\ Nana Shin http://orcid.org/0000-0002-7869-6875}

Received April 30, 2018

Revision received June 1, 2018

Accepted June 4, 2018 